\title{
Power and politics in stakeholder engagement: farm dweller (in)visibility and conversions to game farming in South Africa
}

\author{
Femke Brandt $^{1}$, Jenny Josefsson $^{2,3}$ and Marja Spierenburg $^{4}$
}

\begin{abstract}
Here, we discuss tensions inherent in multistakeholder approaches addressing conflicts over natural resources as well as the involvement of stakeholders in research. Our discussion is built on knowledge generated by extensive research on the impacts of private farm conversions to game farms in South Africa, where significant increases in farm conversions have been observed since the 1990s. The studies had a particular focus on the consequences for farm dwellers, one of the most marginalized groups in the South African countryside. The research findings challenge the dominant narrative that game farming offers a win-win situation for nature conservation and rural development. Based on data from the Eastern Cape and KwaZulu-Natal provinces, we extended the narrow technical and economic framing of the narrative to include the socio-political meanings of the conversions. We reflect on a series of multistakeholder workshops that we organized, partly as a requirement of the funding agency. The workshop aims were to disseminate our research findings among the stakeholder groups and explore ways to mitigate the negative impacts of conversions. We discuss how we organized the engagement process in ways that sought to address the power differences between game farmers, the State, and farm dwellers. The main challenge appeared to be that farm dwellers were not recognized as stakeholders. This "invisibility" has multiple reasons, in particular, the historical and current trajectories of land dispossession. It is also linked to specific institutional and personal relations in the two provinces, resulting in different uses of the workshop spaces. By considering the complexities of stakeholder relations in the farm conversion context, we gained a deeper understanding of the politics of land and belonging in the still unequal postapartheid rural landscape. Based on experiences from the research as well as the workshops, we take a critical stance regarding mainstream notions of stakeholder engagement and resilience building. We argue that if we fail to consider power relations and politics explicitly in these processes, we risk neglecting important conflicts and reproducing the invisibility of marginalized stakeholders.
\end{abstract}

Key Words: conflict; farm dwellers; farm workers; game farming; multistakeholder approaches; power relations; stakeholder engagement; South Africa; violence

\section{INTRODUCTION}

Here, we discuss the tensions inherent in multistakeholder approaches to address conflicts over natural resources as well as the involvement of stakeholders in research. Such approaches frequently aim for the development of a common understanding of the problem at hand, as well as conflict resolution or mitigation, and thereby mainly focus on outcome rather than process (Parkins and Mitchell 2005). A common risk is that power relations and inequalities, often developed over long periods of time, are ignored. As the editors of this special feature note, in situations of strong power asymmetries, conflict may be a healthy expression of resistance, and cooperation may actually be the result of subjugation (E. Fisher, M. Bavinck, and A. Amsalu, unpublished manuscript). They therefore argue for a need to move away from seeing conflicts as undesirable and toward considering them as an important step in the transformation of natural resource management.

In relation to this argument, we signal somewhat conflicting tendencies in sustainability science. The recognition that social and ecological systems are interconnected (Cundill et al. 2005, Fischer et al. 2015) has resulted in strong emphasis on the need to involve stakeholders in research on social-ecological change and to find ways to integrate their needs and knowledge in research (Deppisch and Hasibovic 2013, Mauser et al. 2013). Research funding organizations have absorbed these ideas and often demand that researchers form consortia that include societal partners, from both the public and private sectors. The idea is to involve stakeholders from the start in the process of defining research problems and questions, as well as in developing the research design, and ultimately work toward coproduction of knowledge. It is assumed that this will facilitate the emergence of a common understanding of social-ecological problems, as well as the smooth uptake and implementation of both new knowledge and proposed solutions (Cundill et al. 2013, Mauser et al. 2013). Stakeholder involvement, therefore, is believed to contribute in a positive way to resilience, which is also increasingly defined in a social-ecological manner (Deppisch and Hasibovic 2013).

However, there is a growing body of literature that recognizes the importance of power dynamics in collaborative governance for sustainability (Voß and Bornemann 2011, Barnaud and van Paassen 2013) as well as in transdisciplinarity and global environmental change research (Cundill et al. 2013, Tengö et al. 2017). This literature builds on critical perspectives that emerged in community-based natural resource management studies on multistakeholder approaches (Edmunds and Wollenberg 2001, Larson and Ribot 2004, Dressler et al. 2010). The critique is that these approaches tend to revolve around an assumed "neutrality" of research as a space for engagement where everyone's voice can be heard (equally) and focus on consensus building in contexts in which it might not be desirable for all parties (Barnaud and Van Paassen 2013). In reality, multistakeholder dynamics often serve the powerful stakeholders and silence or exclude marginalized peoples even further (e.g., Edmund and Wollenberg 2001, Ramutsindela 2007, Spierenburg et al. 2009, Voß and Bornemann

\footnotetext{
${ }^{1}$ Department of Anthropology and Development Studies, GES Postdoctoral Fellow, University of Johannesburg, South Africa, ${ }^{2}$ Geography Department, University of the Free State, South Africa, ${ }^{3}$ Department of Organization Sciences, VU University, The Netherlands, ${ }^{4}$ Radboud University Nijmegen, The Netherlands, Stellenbosch University, South Africa
} 
2011, Balvanera et al. 2017). As a result, studies of collaborative governance for sustainability increasingly focus on strategies to deliberately bring to the foreground the needs and knowledge of marginalized stakeholders (Voß and Bornemann 2011, Cundill et al. 2013, Tengö et al. 2017).

Our contribution aims to connect insights from this aforementioned literature and build on the more critical perspectives, but it also calls attention to the importance of the historical social-ecological context in which resource conflicts develop. As E. Fisher, M. Bavinck, and A. Amsalu (unpublished manuscript) write, the everyday contestations over land, power, and belonging are embedded "within social and power relations that are framed by local histories and connected to wider processes of capital accumulation and political dynamics." To increase our understanding of these relations, we embrace their proposed practice of "conceptual convergence" by treating environmental developments as political projects with layers of conflict and issues.

This article is based on findings from and reflections on a research program aimed at studying the impacts of conversions of commercial farms to wildlife-based production, more commonly known as game farming, on farm dwellers in two provinces of South Africa. The conversions took place in local contexts of longstanding conflict over land and other natural resources, which shaped the relations between stakeholders. Structural violence and processes of marginalization are entrenched in these landscapes, in essence, as a result of South Africa's colonial and apartheid regimes. The relationships reflect largely unchallenged patterns of paternalistic and patriarchal relationships that perpetuate the oppression of black people and of black women in particular (Waldman 1996, AFRA 2004, Devereux et al. 2017, Eriksson 2017). One could argue that the social resilience of these relationships is strong, but in a negative way, because it hampers positive transformation and power redistribution. These dynamics had important impacts on our research as well as on the multistakeholder workshops.

An important outcome of our reflections is that although the researchers considered farm dwellers to be legitimate stakeholders, this stance was not, and still is not, supported in the broader political context, meaning that, for example, landowners and government officials to a large extent did not consider the impacts of farm conversions on this group, nor ascribed them stakeholder status (see Bologna 2008). Here, we analyze the relations with and between the various stakeholder groups in our research and workshops and demonstrate how different historical and socio-political contexts in two provinces resulted in differences in how the workshop spaces were used.

\section{SITUATING THE RESEARCH PROGRAM}

The conceptualization of the program was a collaborative effort by a group of South African and Dutch anthropologists, geographers, and political economists, alerted by the visible changes occurring in familiar landscapes in South Africa's countryside, resulting from farm conversions. From the outset, the positionalities of the research team were influenced by the decision to focus on the impacts of farm conversions on farm dwellers. Farm dwellers are people who consider as their home the commercial farms on which they live but do not own. Many of them are farm workers, ex-farm workers, or former labor or rent-paying tenants (Del Grande 2006, Yeni 2018). Much of the literature on game farming that had appeared by 2007 focused either on species and conservation issues or on revenues generated by what was in general referred to as the wildlife industry (see Nell 2003, Langholz and Kerley 2006, Cousins et al. 2008). Commissioned studies suggested that the shift to game farming was addressing both environmental problems such as soil erosion resulting from overgrazing as well as the problem of increasing unemployment in the South African countryside (Langholz and Kerley 2006, Snowball and Antrobus 2008). Little research looked critically at the distribution of benefits of game farming among the various stakeholders, with the exception of a study by Luck (2005) and reports issued by the Association for Rural Advancement (AFRA; AFRA 2004) and the Eastern Cape Agricultural Research Project (ECARP; ECARP 2006).

At the time of the development of the research program (in 2007) there was a clear gap in the academic literature and knowledge concerning the socio-political impacts of game farming. Inspired by the exploratory reports by AFRA and ECARP, the team decided to focus the research on the consequences for farm dwellers. Farm conversions tend to be presented as a "win-win" strategy, contributing both to nature conservation and local economic development, mainly through job creation in tourism. Without rejecting these assumptions of "trickle down" upfront, the program set out to analyze these discourses and knowledge claims by departing from the experiences of the most marginalized and invisible stakeholders.

The main funding agency, the Netherlands Organisation for Scientific Research-Science for Development (NWO-WOTRO), influenced the development of the research by placing a lot of emphasis on both stakeholder involvement as well as on strategies for conflict mitigation and policy change. In concrete terms, NWO-WOTRO required the organization of multistakeholder workshops to further develop the research questions and design presented in the research proposal. NWO-WOTRO also requested a dissemination plan and a "log frame" (an analytical tool designed to plan outcomes and indicators to measure outcomes). This meant that the methodological approach was influenced by expectations of desirable outcomes and the idea that certain steps and actions had to be implemented during the course of the project to arrive at positive policy impacts. However, based on research experiences in South African rural and "wilderness" contexts, as well as an examination of relevant literature, the researchers were well aware of existing power contestations and potential challenges with the funder's model of stakeholder engagement.

We first provide a brief overview of the knowledge base informing the reflection process. The research team involved five senior researchers, six doctoral students, six masters students, and two honors students. The team consisted of Southern African and European researchers and students. In-depth ethnographic case studies were conducted on four "hunting farms" in the Eastern Cape and seven game farms (for both hunting and nonconsumptive tourism) in KwaZulu-Natal, which included the mapping of conversion histories and farm dweller settlements and studies of everyday life at the farms. In addition, in-depth interviews were conducted with 12 game farm owners or managers in KwaZulu-Natal and with 23 game farm owners or managers 
in Eastern Cape (representing various forms of game farming) on conversion histories and motives, employment on the farms, farm dweller histories, and management practices. One $\mathrm{PhD}$ student conducted an ethnographic case study of the Wildlife Forum in which stakeholders (except farm dwellers) at the national level meet to discuss legislation, and another $\mathrm{PhD}$ student analyzed the institutional context of game farming in KwaZulu-Natal. In KwaZulu-Natal, five farm dweller communities participated in the research, including three who were involved in land reform processes. In the Eastern Cape, (former) farm dwellers from game farms were interviewed in three townships or informal settlements. In total, > 250 interviews were conducted with different stakeholders, including national and local government officials, nongovernmental organization (NGO) staff, conventional farmers, owners of game farming or farming service industries, tourism entrepreneurs, and nature conservation organizations. Numerous informal conversations and (participant) observations were conducted during wildlife auctions, meetings, hunting and wildlife tracking courses, on farms, and in townships and informal settlements. The series of multistakeholder workshops discussed here contributed further to the findings. Before we discuss the research findings, we next present the different historical contexts of agrarian changes in the two provinces.

\section{MAKING FARM DWELLERS VISIBLE AS STAKEHOLDERS IN GAME FARMING}

In both the Eastern Cape and KwaZulu-Natal provinces, the creation of the farm dwellers social category resulted from centuries of land dispossession, the enclosure of land as private property, and the development of capitalist farming under colonialism and apartheid (Van Sittert 2002, 2005, Wels 2015). Here, we provide a brief overview of these trajectories and how they differ in the two provinces. Moreover, we underscore the structural violence entrenched in everyday power relationships in the South African countryside (Manby 2002, AFRA 2004), as well as the resistance to the inequalities characteristic of the natural resource distribution in farming areas. We consider the emergence of game farming as a process with multiple layers, meaning that we include dynamics of contestations of belonging in addition to conservation issues and economic development. It is against this background that we interpret the invisibility of farm dwellers as stakeholders in farm conversion processes.

Over centuries, white landowners and dispossessed Africans developed unequal relations and institutions on commercial farms (Du Toit 1993, Waldman 1996, Mkhize 2012, Connor 2014, Eriksson 2017). In the Eastern Cape, the semi-arid Karoo was transformed into a sheep-farming area producing wool as major export product for the British colony. The private property system introduced by the British transformed colonial society, but also generated resistance from the African population (Peires 1981, Van Sittert 2002, 2005). The search for better wages and working conditions produced a constantly available and mobile labor force for whom access to land for cultivation and livestock became increasingly difficult (Evans 2010). In the absence of State support or services for black people on farms, and in response to the persistent challenge to keep people on the farm, farmers were forced to supplement wages with agricultural produce, education, and healthcare. This constant negotiation and resistance to power by dispossessed black people in turn shaped paternalistic relations on farms in the Eastern Cape (Connor 2014).

Farm dwellers in KwaZulu-Natal have experienced a relatively high degree of autonomy compared to those in Eastern Cape because they often lived on land that was not occupied by the owner (Brooks et al. 2011). Many livestock farmers in the Midlands of Natal acquired additional farms in the thornveld area, which served as so-called labor farms. At certain times of the year, tenants living on labor farms were summoned to the associated farm to work; thereafter, they would return to the labor farm or seek work in the Transvaal mines; McClendon (2002) refers to them as "off-site labor tenants". In effect, the northeastern region of the province served as a source of cheap labor for Midland farmers. The evolving system of labor tenancy became an entrenched feature of the social history of the region (McClendon 1995, 2000) despite various attempts by apartheid governments to destroy this setup through legislative and policy measures, as well as through forced removals during the $1960 \mathrm{~s}$ (SPP 1985). As a result, black people and households are present on most privately owned farms (Platzky and Walker 1985).

The different trajectories of land dispossession in KwaZulu-Natal and the Eastern Cape have shaped the relationships and dependencies between white landowners and black workers and tenants on the farms. In her thesis, Mkhize (2012) addresses the puzzle of why contestation and conflict around land tenure are much more visible in KwaZulu-Natal compared to the Eastern Cape. She argues that the much earlier dispossessions in the Cape Provinces created a dependent, servile labor class on the farms as people lost all access to land and independent farming during the 19th century (Mkhize 2012, 2014). Because of the early dispossession, black people have had little opportunity to claim land back under the African National Congress' (ANC) postapartheid land reform program, which targets people who lost land as result of the 1913 Natives Land Act and subsequent discriminatory legislation. In contrast, in KwaZulu-Natal, the system of labor tenancy persisted during colonialism and apartheid. This enabled black people's access to land and grazing fields, which allowed a greater degree of autonomy (SPP 1985) compared to the dispossessed proletariat in the Eastern Cape. It further means that their rights to land and tenure are to some extent acknowledged in post-apartheid legislation. In KwaZuluNatal, many farm dwellers and landowners are currently engaging with the State in land reform processes (see Brandt and Mkodzongi 2018). Mkhize (2012) notes the striking difference in labor-tenant claims submitted in both provinces by 2002: 79 in the Eastern Cape and 7713 in KwaZulu-Natal. Furthermore, in KwaZulu-Natal, land rights organizations are active in multiple social spheres, and there are several restitution farms in the area where we conducted research.

Throughout the country, conversions to game farming predominately take place in commercial farming areas, where most landowners are white and where working conditions and tenure security for farm dwellers have always been precarious (Mkhize 2012, Brandt and Ncapayi 2016). Under the postapartheid democratic dispensation, various attempts have been made to address this situation through the adoption of tenure security acts and labor legislation, which, however, are at odds with the deregulation of the agrarian sector (Spierenburg and 
Brooks 2014). Nonetheless, everyday power struggles on farms still result in evictions of farm dwellers, shaping labor regimes and deeply entrenched violent relations (Manby 2002, Hall 2007).

The political rhetoric of transformation and land reform adopted since the first ANC-led democratic government came into power in 1994 has generated anxiety among white farmers in both provinces (Fraser 2008). Statements in the press by Ministers and Members of Parliament about the need to speed up land reform (Stoddard 2016) require white farmers to legitimize and assert their position on the land. However, subsequent ANC governments have also promoted neoliberal policies, which have resulted in further deregulation and land consolidation (Van Zyl et al. 1996, 2001, Williams et al. 1998) rather than redistribution of land, resulting in a decline in the number of jobs on commercial farms (Vink and Van Rooyen 2009). In addition, there is a notable tendency to replace permanent workers by casual labor (Hall 2007, Aliber et al. 2009, Spierenburg and Brooks 2014). Thus, there is a general trend toward larger farms with fewer owners that absorb less labor in the countryside.

Conversions to game farming have been observed since the $1960 \mathrm{~s}$ (Nell 2003, Wels 2015). From the perspective of landowners, it was perceived to be an economically sound response to declining agricultural markets and profits that set in during the 1980s (AFRA 2004). With the end of apartheid dawning, the Game Theft Act 105 of 1991 strengthened ownership of land and natural resources by changing the status of wildlife from public to private good (Snijders 2015). Since then, farm conversion rates have increased significantly, but how much land and how many farms have been converted is difficult to estimate because changes of land use and ownership are not all registered with government or are only registered with certain departments. Nevertheless, in 2006, the National Agricultural Marketing Council estimated that wildlife is produced on nearly 10,000 commercial farms covering approximately 4.9 million ha (National Agricultural Marketing Council 2006). More recent estimates cite 9000 wildlife ranches, but with an expanded area of 17 million ha (Taylor et al. 2016), amounting to more than one-quarter of all land available for grazing in South Africa. The conversions are often gradual processes that consist of consolidation of farm properties over a period of several years, repeated investments in wildlife species, the fencing or unfencing of areas and demolishing of farm houses and existing infrastructure (Brandt and Spierenburg 2014). During this process, farm dwellers are often forced to leave the farm in search of livelihoods and homes elsewhere (e.g., Brooks and Kjelstrup 2014, Mkhize 2014).

Contestations over land ownership and access to natural resources are an ongoing reality in South Africa's rural areas (see also Brandt and Mkodzongi 2018). They are expressed through formalized land reform procedures and policy and legislative frameworks, as well as through informal or extra-legal methods such as land occupations, illegal cattle grazing, cutting of fences, protests, and sometimes through direct violence. A relatively recent example is the unprecedented uprising of farm workers that occurred on Western Cape wine farms in 2012 and 2013 (Ntsebeza 2013, Wilderman 2015, Eriksson 2017). The terms "unprecedented" and "historic" were used to describe this occurrence because of the extreme power differences on farms. The extremely low wages and poor living conditions for workers and farm dwellers are other aspects of the structural violence that persists in the countryside. Popular rhetoric of rural violence in the countryside disproportionately favors the concerns of farm owners backed up by their powerful lobbies and organizations. Manby (2002:89) states that crimes against farm owners are highly visible compared to the "near invisibility of violent crime against farm residents" (see Brodie 2013, Nicolson 2015). Because "violence has been built into the fabric of white control of the land in South Africa from the start" (Manby 2002:90), extreme inequalities are normalized and are therefore no longer perceived as violent.

In terms of the findings of the research program, we discovered that the win-win narrative of farm conversions is quite hollow. Even scholars who are adamant about the positive impacts of farm conversions on employment creation cite reduced labor demands as an important motive for farmers to shift to wildlifebased production (Langholz and Kerley 2006), a finding confirmed by researchers in our project (e.g., Mkhize 2012, Brandt 2013). Labor demands, however, vary across different modes of game farming. The high-end ecotourism lodges generate more employment than conventional farming, especially for women. However, this is a rather fickle industry; during the first years after the financial crisis, many of the high-end lodges witnessed a dramatic reduction in the number of bookings, and many employees, especially in the lower ranks, lost their jobs or saw their working hours and pay significantly reduced. Most of the jobs created are seasonal and temporary, and former farm workers and dwellers often only have access to these insecure jobs in the lower ranks (Andrew et al. 2013). Other forms of game farming result mainly in the shedding, casualization, and outsourcing of labor (Spierenburg and Brooks 2014). Hunting and breeding farms require particularly little labor. Only a few laborers are kept on to maintain water points or as trackers; on hunting farms, some women manage to obtain jobs looking after the guests in the hunting lodges (Brandt 2013).

Positive statistics provided by other researchers (e.g., Langholz and Kerley 2006, Snowball and Antrobus 2008) are often skewed toward one mode of game farming and fail to take into account the effects of the amalgamation of properties accompanying most conversions. While the owner or manager interviewed may have hired more staff, the numbers often do account for the fact that most of the farm dwellers on the farms acquired to expand the game farm (on average approximately five; see Langholz and Kerley 2006) lost their jobs as well as access to land. It must be noted, however, that shedding and casualization of labor are strategies also deployed by the remaining commercial farmers in South Africa (e.g., Du Toit 2004, 2005, Ewert and Du Toit 2005).

We found that the wildlife industry's claims of job creation, rural development, and conservation are a political strategy, enabled through the commodification of nature, to justify and assert control over land, animals, and people. Game farmers' selfproclaimed identity as custodians of nature is instrumental in the context of post-apartheid rhetoric of land reform and transformation in which white landowners feel the need to legitimise their position on the land (Josefsson 2014, Brandt and Josefsson 2017). The conversions, however, also lead to tensions within the white farmers' community about, for instance, livestock diseases and predator control (Brandt and Spierenburg 2014). 
Table 1. Description of the multistakeholder engagement process.

\begin{tabular}{|c|c|c|c|}
\hline Year & $\begin{array}{l}\text { Netherlands Organisation for Scientific } \\
\text { Research (WOTRO) activity }\end{array}$ & Objective & Participants \\
\hline 2007 & Inception workshop & $\begin{array}{l}\text { Formulate and refine research proposal and } \\
\text { questions }\end{array}$ & $\begin{array}{l}\text { Nongovernmental organizations (NGOs), } \\
\text { government officials from agriculture and } \\
\text { environmental affairs (no game farmers or } \\
\text { farm dwellers) }\end{array}$ \\
\hline \multirow{5}{*}{$\begin{array}{l}2008 \\
2011\end{array}$} & Explorative field visit & Establish contacts in the field & \\
\hline & Eastern Cape multistakeholder workshops & & \\
\hline & $\begin{array}{l}\text { 1. Farm dweller workshop in township, } \\
\text { Saturday morning }\end{array}$ & $\begin{array}{l}\text { Discuss findings with farm dwellers first; take } \\
\text { selected representatives to next workshop in } \\
\text { town with other stakeholders, including game } \\
\text { farmers }\end{array}$ & $\begin{array}{l}\text { Local NGO with farm dwellers (not the farm } \\
\text { dwellers who participated in the research), } \\
\text { local advice office members }\end{array}$ \\
\hline & 2. Town workshop, evening & $\begin{array}{l}\text { Present and engage findings to interested } \\
\text { local stakeholders }\end{array}$ & $\begin{array}{l}\text { Local farmers, local government, local } \\
\text { business, Advice Office representative, } \\
\text { Southern Cape Land Committee, journalist, } \\
\text { academics, National Park conservation } \\
\text { manager, accountant, estate agent, police } \\
\text { officer }\end{array}$ \\
\hline & 3. City workshop, Port Elizabeth, whole day & $\begin{array}{l}\text { Present research findings; influence policy by } \\
\text { engaging government? }\end{array}$ & $\begin{array}{l}\text { Game farming organization representative, } \\
\text { government officials in nature conservation, } \\
\text { NGO representative }\end{array}$ \\
\hline \multirow[t]{3}{*}{2012} & KwaZulu-Natal multistakeholder workshops & & \\
\hline & 1. Rural town workshop & $\begin{array}{l}\text { Present findings to and engage interested } \\
\text { local stakeholders and obtain further } \\
\text { information on dynamics relevant to the } \\
\text { stakeholders }\end{array}$ & $\begin{array}{l}\text { Farmers, farm dwellers, land beneficiaries, } \\
\text { land activists, land rights NGO, a local inkosi, } \\
\text { tourism operators, the provincial nature } \\
\text { conservation organization, the research team }\end{array}$ \\
\hline & 2. City workshop, Pietermaritzburg & $\begin{array}{l}\text { Present findings to and engage interested } \\
\text { local stakeholders and obtain further } \\
\text { information on dynamics relevant to the } \\
\text { stakeholders }\end{array}$ & $\begin{array}{l}\text { Nature conservation organizations, land rights } \\
\text { NGOs, national and provincial government } \\
\text { staff, the research team }\end{array}$ \\
\hline
\end{tabular}

Furthermore, trophy hunting businesses clash with conservationist ideals because of selective stocking, breeding, and killing practices in the sector (Snijders 2014).

For farm dwellers, conversions tend to perpetuate dispossession from natural resources and further displacement from land (Mkhize 2014, Spierenburg and Brooks 2014). In several instances, this situation has resulted in contestations over land, belonging, and notions of "rights," sometimes with dire material and emotional consequences for farm dwellers (Brooks and Kjelstrup 2014). In the Eastern Cape, farm dweller life trajectories are characterised by constant mobility to evade farmers' control over their lives, as well as attempts to establish secure homes or places of belonging off-farm, if needed (Brandt 2013). Similarly, for KwaZulu-Natal, Josefsson (2014) argues that farm conversions work against rural transformation. Ngubane and Brooks (2013) show examples of the interplay between land restitution and wildlife production on private land in a so-called community game farm set-up. In relation to the State, research shows that wildlife policy-making processes enabled a strategic arena for land and wildlife owners to promote their interests over those of farm dwellers (Kamuti 2014).

\section{ANALYZING THE MULTISTAKEHOLDER ENGAGEMENTS IN THE RESEARCH PROGRAM}

In Table 1, we outline the timeline and stakeholder engagements of the research program. We indicate the period over which relationships were built with stakeholders, from the program's inception until the completion of the final workshops. Note that the fieldwork took place within this timeline, but research has since continued in some areas. For this and the following sections, we rely on meeting records, field notes, reflections and discussions, workshop reports, and our presentations to reconstruct the research process and events in the two provinces.

Starting stakeholder engagements as part of the research process As required by the funding agency and the research program's implementation plan, we organized a project inception workshop in the spring of 2007 with a number of stakeholders attending. The stakeholders were mainly from what we then thought were relevant sectors: government departments (agriculture and environmental affairs) and civil society organizations. Two groups of stakeholders were conspicuously absent from these workshops: game farmers and farm dwellers. Members of the first group indicated that they were too busy, and farm dwellers were difficult to mobilize within our short turnaround time and in the early stage of the project. We therefore relied on civil society organizations to represent farm dwellers' interests, and notably, some government officials took it upon themselves to represent game farmers.

Together with these groups, we refined our research questions. Some participants, including some government officials, objected to the focus on farm dwellers and thought that we should look at broader effects (translated mainly as revenues generated), but we maintained that focus while emphasizing our independence. We explained that we would critically examine whether or not game farming was a win-win strategy for conservation and development 
and we indicated that we would not beforehand exclude either possibility. This stance proved vital in obtaining access to the field, and especially to farm dwellers residing on farms. In addition to the workshop, we tried to contact some of the "missing" stakeholders during exploratory field visits and managed to contact conventional farmers, game farmers, and staff members of official organizations such as the Eastern Cape Game Management Association. The farm dwellers, however, remained invisible.

We were aware of the sensitivity of the research issues and the strong emotions they elicited. Nevertheless, our research was welcomed, but stakeholders had contradictory expectations. Game farmers were convinced we would prove that farm conversions are the ultimate solution to the social and environmental problems of the countryside; civil society organizations were convinced that we would prove that the conversions would result in nothing but misery for farm dwellers; and conventional farmers predicted that our outcomes would demonstrate that game farming destroys the farming sector.

Once the funding was granted, we organized a follow-up workshop in the provincial capital of KwaZulu-Natal, where some participating students presented their individual research projects. During this workshop, some tensions rose because some of the civil society organizations, which had endorsed the project, demanded that in return they would be given access to the raw data, including names of landowners, so they could use this for legal actions. We refused mainly for two reasons. Firstly, it would be a serious violation of the general ethical codes of academia and research. Secondly, we were dependent on farmers and landowners for access to both places and people and we could not risk compromising their willingness to participate (this still turned out to be a problematic negotiation; see Brandt and Josefsson 2017).

Implementing the research project required continuous engagement with the stakeholders, especially by the masters and doctoral students conducting most of the research. While our contacts with game farmers and their organizations somewhat facilitated access to game farms and farmers, there were different experiences among the team members regarding negotiating access. This was in essence related to the researchers' different positionalities, shaped by race, gender, nationality, and seniority (Mkhize 2012, Kamuti 2016). In general, it was harder for black South African students to access or establish rapport with white farmers because they were less welcomed than were white European students and researchers. The female researchers' experiences also revealed the gendered nature of the game farming landscape (Brandt and Josefsson 2017).

When access was granted, this was often by farm owners who believed they were decent employers. Nevertheless, it proved to be very difficult, sometimes even impossible, to speak to farm dwellers on farms without owners or managers being present. The team tried other strategies to make contact with farm dwellers, for example, when they visited relatives and friends outside the farms. Especially in KwaZulu-Natal, where conflicts over land in some areas have taken a violent turn, this was not without risk. Although violence is also part of everyday life on Eastern Cape farms, as a continuous undercurrent of structural violence, open confrontations were much rarer.
The team's relationships with civil society organizations varied over time. With some, we remained in contact, exchanging ideas and experiences, and some of the research participants organized workshops with or for them. Other organizations either moved on to other issues or lost interest when our research did not result in data they could use immediately in campaigns or lawsuits. Our initial plans to identify conflict mitigation strategies in cooperation with these organizations turned out to be impossible. This was also related to the tensions we encountered in the field. For example, relations with the game farmers' organizations soured when our results did not confirm the positive image they were trying to promote. One incident was sparked by a presentation given by two doctoral students at Rhodes University (Eastern Cape) on their preliminary findings, during which members of the national and local game farming organization were present. After a fierce debate, in which the students were accused of conducting sloppy research, a representative of the national game farmers' organization sent out an email to all members warning them not to cooperate with our group and advised them to deny us access to the farms. This warning sparked a new round of access negotiations for the researchers already in the field, as well as for researchers entering the field at later stages, because it negatively influenced the attitude of some game farmers.

It was in this volatile context that, toward the end of the project, we organized a series of workshops to disseminate our research findings to the stakeholders. Although the funding agency mentioned multistakeholder approaches as an important (dissemination) tool, we adapted this approach somewhat as we will discuss below, in response to the power configurations we encountered in the field. In line with some of the critiques of this approach (Voß and Bornemann 2011, Barnaud and Van Paassen 2013), we decided to first focus on the most vulnerable stakeholder group we identified, namely farm dwellers.

\section{Eastern Cape stakeholder workshops: struggles with access and participation}

We opted to organize a sequence of two workshops in the rural town where two of the doctoral researchers had been based during their field research: the first in the township and the second in town itself. After these workshops, a third was organized in Port Elizabeth. The main aim was to report back what knowledge the research had generated and discuss how it could be relevant to the different stakeholder groups, notably farm dwellers, NGOs, and relevant government officials. The biggest challenge was organizing the workshops one year after two doctoral students completed their fieldwork in that region. In the context of limited phone and computer-based communication, relationships had been based on face-to-face interactions and the physical presence of researchers. The available two weeks were too short to reconnect and trace farm dwellers who had moved in the intervening time.

The first workshop organized in the township was to enable a platform exclusively for farm dwellers and representatives of organizations that support farm dwellers. The aims were to discuss the research findings with farm dwellers and prepare willing participants to come along to the second workshop in town that would involve a discussion with a broader array of stakeholders, including local game farmers. Although the research focus was 
on the consequences of farm conversions for farm dwellers, we framed it as follows: "From merino to rhino: the socioeconomic impacts of wildlife ranching in the Eastern Cape." This framing was an attempt to be inclusive, a balancing act in a context of extremely antagonistic participants. In the end, this performed "neutrality" made no difference to how the research team was perceived. On the way to visit farm dwellers on a trophy-hunting farm, one team member met a farmer who asked why she was back in the area. When she explained the workshops, a discussion about labor and land issues ensued, and the encounter ended tensely. She later found out that the farmer had phoned a game farmer participating in the research to ask why he let that "socialist" onto the farm "stirring up trouble among the workers." The game farmer emphasized that the researcher must understand that "farmers feel threatened" by the political shifts in postapartheid society. Neither the game farmers nor any of the farm dwellers from the case study farms attended the workshops.

The 15 participants of the first workshop in the township were members from the local Legal Advice Office, the Southern Cape Land Committee (SCLC), and a few community members who had learned of the meeting through Advice Office pamphlets distributed the preceding week. This attendance was despite the arrangement of transport for workers who had indicated they would be able to come on a Saturday. Farm dwellers' decision not to participate could be explained by fear to jeopardize their relationship with farmers, the heavy rains that made farm roads inaccessible, or the realistic assumption that it would be unlikely that the researchers would be able to address their issues effectively.

The presentations and conversations were conducted in Afrikaans because few participants spoke English, and occasionally, isiXhosa translations were provided by the participants. Farm dwellers who came with SCLC responded to the researchers' presentations with keen interest. In affiliation with SCLC, they have formed farm committees through which they negotiate with farmers about their working and living conditions. They spoke about how they lost their fear of farmers once they were organized in committees. One of the SCLC organizers indicated that it had taken them two years to build enough trust to establish the committees. They hoped the workshop would offer an opportunity to work with farm dwellers in this region, where they had always struggled to organize farm dwellers because of the extreme inequalities and violence on farms. She pointed out that labor laws, land reform policies, and the constitutional protection of private property pose significant problems for rural transformation.

Although the meeting facilitated relationships between the NGOs, it did not achieve what we envisioned, namely to report back our research findings to the participants of the research and mobilize farm dweller participants for the next workshop. Moreover, we do not know what effect it had or what happened with the information shared and exchanged. To a large degree, the results were beyond the control of researchers, especially because the research program was ending, and we were leaving the field, as researchers often do.

A couple of days after the first workshop, a follow-up workshop took place in one of the town's museums. Again, the participants were interested parties who had no direct relation to the farms that were part of the research. In addition, one staff member of SCLC was the only participant who had attended the previous workshop. With the exception of some of the researchers and some local government officials, the majority of participants were white. When participants were invited to introduce themselves, the latter participants emphasized they had come in their private capacity. They explicitly disassociated themselves from any stakeholder label and refused to represent any specific group. Nevertheless, they were present and adopted discourses that protected white farmers' interests. Some stressed the need to reduce labor costs while at the same time calling for more skilled laborers. Some argued for the separation of employment from home and land rights, promoting the idea of the establishment of agro-villages for workers in the region, suggesting that the research group should formulate policy recommendations in support of this. Other voices challenged these views by talking about their experiences with power dynamics on the farms, for example, inspectors from the labor department, who struggle to speak to workers alone, without presence of farmers. Toward the end, the workshop facilitator pointed out that we had talked about farm dwellers as "farm workers" throughout the evening, as if they would remain that forever. He asked what participants thought about their need for land and their future as farmers. In the days after the workshop, several participants told one of the team members that they felt discriminated against as white South Africans: "Certainly we don't want to reverse apartheid," they said. For them, redistribution of land and rural transformation would mean an oppressive system dominated by black people. To consider giving up privilege and property for the sake of a more egalitarian and democratic society seemed unimaginable, undesirable, and frightening.

The last and third workshop took place at a university in Port Elizabeth. Again, people we had engaged with during other phases of the project were absent, except for the SCLC representative. At this workshop, the representative from Wildlife Ranching South Africa was very vocal about his dissatisfaction with the research findings. He accused the researchers of working with "the wrong data" and made it very difficult to create space for other voices to be heard. In the discussions, government officials, including black people appointed after 1994, supported his claims that game farming generates employment, and that small-scale farming does not lead to development. During the tea break, however, in private conversations with one of the researchers, some of the officials expressed different views that were much more supportive of farm dwellers and small-scale farmers. However, none of the officials aired these views in public, and interviews held after the workshop revealed that provincial authorities are very reluctant to consider land claims on game farms.

All three workshops faced issues with the representation of both farm dwellers and game farmers. Those representing these groups, including the NGO staff, were not the people from the game farms who had participated during the research process. This raises questions about accountability and the value and meaning of sharing research findings and engaging with conflict. Whether these conflicts can be solved locally is a moot point. Provincial and district authorities could play a role by engaging with local stakeholders and taking land claims seriously; however, they lack resources and capacity, and, in this province, seemed to buy into the discourse that game farming is a win-win strategy. 


\section{KwaZulu-Natal workshops: confrontation and repentance}

For the KwaZulu-Natal workshops, the team had the benefit of learning from the dynamics and experiences in the Eastern Cape, which certainly helped with conceptualizing and implementing the workshops. However, our suggestion to start with a separate workshop for farm dwellers was rejected by the farm dwellers because they wanted to engage directly with the game farmers. This was already an indication of the different dynamics in the area compared to the Eastern Cape. To facilitate farm dweller and land reform beneficiary participation, we organized transport for participants to and from the workshops. We also employed one of the researchers' field assistants, "Khanda," who interpreted and facilitated the workshops in isiZulu, to address the power dynamics of language.

We held three workshops in the province: one in the provincial capital Pietermaritzburg because several key government departments and NGOs are located there, and two in a small town near the case study sites. We decided on two local workshops, hoping that this would facilitate attendance for as many stakeholders as possible, and indeed, each workshop had approximately 20 participants. We invited stakeholders who had either been interviewed or otherwise participated in the research, as well as those whom the research participants recommended that we invite. All stakeholders were given the option to participate in all three workshops, and as expected, most farm dwellers, farmers, and land beneficiaries took part in the town workshops, probably because of the proximity to the farms.

Just like in the Eastern Cape, the process of inviting participants relied heavily on being present in the area and our personal relationships with stakeholders. For the town workshops in particular, communication via email or phone calls was not an option because of limited access for many stakeholders. An important difference was that in KwaZulu-Natal, the fieldwork was still ongoing. The team, therefore, saw the workshops as an opportunity to expand and elaborate on the fieldwork and to explore new or additional aspects in collaboration with the stakeholders. We made this clear in the workshop preparations as well as in the workshops and tried to keep it open for interpretations and trajectories that we had overlooked or which were important to the participants.

In the town workshops, the participants consisted of white game farmers or farm managers and black so-called land beneficiaries. The land beneficiaries were also game farmers; they had been "encouraged" to continue with game farming when on land that was returned to them (Ngubane and Brooks 2013). However, the historical and political context of land dispossessions and land reform has generated a certain terminology that perpetuates the invisibility of black farm dwellers in positions other than as recipients of decisions (Ramutsindela 2012, Eriksson 2017). In addition, there were farm workers and farm dwellers, land claimants, and an inkosi (local chief) whose constituency includes one of the team members' case study farms. Representatives of the provincial nature conservation agency Ezemvelo KZN Wildlife and local tourism operators were also present. The participation of two land rights activists, both with long-standing experience in private property debates, land reform, and fighting dispossessions, functioned as both experts and stakeholders. Their experience was evident in how they claimed space and questioned mainstream discourse, in comparison to many other participants. This brings attention to how the format of multistakeholder workshops is something to be learned, and not a "given" mode of communication or conflict resolution.

Despite our efforts to facilitate participation by farm dwellers, this was restricted. In one case, the game farmer told one of the researchers that "his people" were not allowed to participate in the workshop because they had too much work to do. He did not participate himself either. Another game farmer phoned that same researcher and was very angry that she had spoken to "his staff" about the workshops and said that she was not supposed to invite anyone but him. In the end, very few white-owned farms had representation from workers or farm dwellers. In one case, however, the farmer brought the man he considered to be the representative of his workers. All of these responses show that participation was neither apolitical nor considered an individual choice. The farmers still decided, directly or indirectly, who from "their farm" was allowed to participate. This resonates with the Eastern Cape experience of game farmers and game farmer representatives trying to control the research process as well as the workshops.

During fieldwork, the team became aware of some very violent and traumatizing events that farm dwellers had experienced. Many had gone through farm evictions, either carried out by the State during apartheid or enforced by farmers post-1994. There were farmers in the workshops who had been involved in conducting illegal evictions, and some of the people they had evicted were present. The team had also come across several instances in which farm dwellers had retaliated with various forms of violence against evictions and oppression. Nevertheless, despite these dynamics, the experiences in the two town workshops challenged our expectations. Once we were in the actual workshops, the narratives were far less dominated by those (we perceived as being) in positions of power than we had presumed. Based on the Eastern Cape experience, as well the antagonism that some farmers expressed during the workshop preparations, we had expected the game farmers to try to dominate the process. However, the discussions turned out to be far more equal than we had anticipated in terms of sharing the space and allowing different voices to be heard. At times, there were open contestations, especially regarding land redistribution and land use; these debates got tense but never ended in open (aggressive) conflict.

During fieldwork, the team had observed that farmers often spoke about their wrongdoings against "people" (Africans) in the past, and it was clear from the context that they were referring to the evictions. They confessed to having mistreated farm labor, as well as their own families (referring to alcohol abuse and abusive behavior). These confessions appeared to be influenced by the Mighty Men movement (see Nadar 2009, Dube 2015, Davis 2017) and the call from its leader Angus Buchan to white farmers to find their way back to God and become a kind of benevolent but firm Christian patriarch (see http://www.mightymenconference. co.za). Many farmers mentioned the Mighty Men movement as a source of inspiration and guidance for their changed lives. This somewhat reflective and pious attitude revealed itself during the workshops as well, and, we believe, influenced participants' behavior. On a couple of occasions, farmers approached the 
researchers to explain how they are listening to "the people" now and how they have changed compared to how they used to behave in the past. It is possible that this contributed to farm dwellers' relative visibility in the workshops. Nonetheless, this "new" identity does not challenge the existing power hierarchies. In fact, it allows farmers and landowners to maintain their positions as ("benevolent") patriarchs and entrench their belonging in the farming landscape.

The participation of land activists and the strong presence of advocacy and activist organizations in the province also contributed to the more equal use of space in the workshops compared to the Eastern Cape. The fact that open contestations are common between the stakeholders most likely influenced the workshop dynamics as well. Farm dwellers are much more visible in the KwaZulu-Natal rural political landscapes than are farm dwellers in the Eastern Cape. Lastly, the stakeholders also found common ground in terms of their frustration with the State and their struggles with big capital ventures. The participating farmers owned fairly small-scale family farms. They felt that the State only focused on and invested in large-scale farming, which generally strengthens the position of those who already possess significant capital and assets. Another shared frustration was the State's lack of clarity, action, and support regarding land reform and labor rights, which was experienced as disempowering and fostering uncertainty. In many cases, stakeholders have been waiting for years for resolution to claims and disputes or for promised financial or material support. While the frustrations with the State and capital appeared genuine, and, as suggested by one activist, offered an opportunity for collaboration between the different stakeholders, the focus on a "common enemy" could also serve to detract attention from conflicts and power imbalances between the stakeholders present.

Apart from representatives of the provincial conservation agency, no other government departments participated, hence no responses to these frustrations were provided. In fact, most government representatives did not reply to the invitations, which makes it difficult to analyze their reasons for absence. However, at the workshop in the provincial capital, where the department of agriculture was represented, government officials publicly expressed more diverse views than those at the provincial workshop in Eastern Cape. Whereas some supported game farming, others did question its validity in relation to land claims and land rights.

\section{DISCUSSION}

The main insight generated by the multistakeholder workshops and the engagement process was that farm dwellers were not considered as active stakeholders in the game farm conversion processes (Bologna 2008), either by farmers or the State, although there were some notable differences between the two workshops series. Because of participation in ongoing land reform procedures and experience with institutional processes, farm dwellers in KwaZulu-Natal were more visible in contestations over land and belonging. At the same time, patriarchal relations remained firmly in place and were difficult to challenge. In the Eastern Cape, contestations were entrenched in more "hidden forms of resistance" (see Scott 1985); farm dwellers as well as game farmers who had participated in the research opted to not participate in the workshops at all.
Meaningful inclusion and participation (see Parkins and Mitchell 2005) of stakeholders proved very difficult and complex. In hindsight, we have realized that we focused mainly on content, reporting back on our findings and challenging the win-win discourse. Although we aimed to address the power disparities and include farm dwellers by organizing a stepwise series of workshops, participation did not necessarily lead to meaningful engagements or transformation of power relations (see Cooke and Kothari 2001). In addition, the limited resources available to us for planning and preparations also affected the engagement process. A clear example of this effect is that we could not do follow-up interviews or assessments of the impacts of the research and the workshops.

An unexpected dynamic that emerged in one of the KwaZuluNatal workshops was that the stakeholders found common ground in their frustration with the State and large-scale commercial farming. To some extent, this common ground fostered a discussion around shared experiences. However, farm conversion, land consolidation, and market deregulation have had significantly different effects on farmers and landowners compared to farm dwellers, who undoubtedly have suffered far worse adverse effects (Connor 2014, Mkhize 2014, Brandt and Ncapayi 2016, Devereaux et al. 2017). In this regard, the discussion still did not address issues of power inequalities or the disparities in access to land and resources.

Positionality and the levels of trust and networks of research relationships shaped the workshop dynamics in both provinces. As researchers, we are often perceived or expected to possess some sort of unique or pivotal knowledge that could solve the problems at hand. This does not mean that we were always trusted by the participants. On the contrary, we found that the academic position also brought about distrust in many cases, especially in the relationship with farmers and landowners, once they felt the research findings might jeopardize their win-win narrative. However, had it not been for interpersonal relationships, it would have been nearly impossible to organize any workshops at all. Other stakeholders also held the privilege of being "experts" in their specific fields, for example, those representing the wildlife industry, nature conservation organizations, and land activists. There was a bias toward those with formalized education and experience in the powerful sectors (see Parkins and Mitchell 2005, Derkzen and Bock 2007) in terms of who claimed to advocate "truths" and best practices. This perpetuated the invisibility of farm dwellers and their poor chances for meaningful participation.

This situation raises concerns about who was allowed or felt comfortable to claim space in the workshops, and furthermore, who was considered to have the skills or knowledge to take decisions or come up with workable solutions. The question of which kind of knowledge or expertise takes preference is important here. In South Africa, this idea is linked to a longstanding tradition of paternalism (Ewert and Du Toit 2005) and stereotypical ideas about farm workers (Waldman 1996, Bolt 2017, Eriksson 2017). Farm dwellers' invisibility means that they are often not considered as legitimate decision makers or claim makers. This illegitimacy is reflected in the problem of identifying conflicts. Both the State and game farmers tend to claim that they know what is best for "their people," but what about the farm 
dwellers themselves and their knowledge? If trust is placed in experts who are also empowered to take decisions for others, the process of exclusion deepens as control over the outcome is moved further away from those who depend most directly on the resource (Parkins and Mitchell 2005). Policy makers tend to have a limited understanding of farm dwellers' livelihood structures, which means that they are poorly recognized or represented in rural transformation programs (Del Grande 2006).

Those in positions of power tend to be (more) visible in both process and outcomes than those not in power (Edmunds and Wollenberg 2001, Faysse 2006). This situation brings us to issues of complicity and responsibility for the impacts of our research because we decided whom to invite and not to invite, how the workshops were conceptualized and conducted, and to some extent, what was being discussed. In this regard, we became stakeholders too, and potential drivers of change. Our findings and interpretations, as well as the knowledge we generated, shaped the stakeholder engagement and the workshop dynamics, dispelling the myth of researchers as neutral or objective (Edmunds and Wollenberg 2001). Yet, as far as we could tell, in sharing and engaging with participants in the research findings, we were not able to influence power disparities during the workshops or convince participants of the problems with the dominant discourse on game farming as a win-win strategy for conservation and development.

\section{CONCLUSION: WHOSE RESILIENCE?}

While the call for more stakeholder involvement in sustainability sciences is laudable, our experiences show that this is far from a straightforward process. Our reflections have revealed that the question of who is considered a stakeholder or legitimate claimant shapes both conflicts and resilience. Similarly, the question should be asked: Whose resilience is strengthened or enhanced on the basis of what kind of politics that are reflected in multistakeholder engagements? The rationale behind the call is partly related to a desire to be inclusive and partly pragmatic in the hope that it will result in more support for and smoother implementation of solutions (Mauser et al. 2013). The latter reason suggests a focus on outcome, rather than process, which can be quite problematic, as already suggested (see Parker and Mitchell 2005). Instead, meaningful and inclusive stakeholder engagement requires significant attention to process (Parker and Mitchell 2005, Barnaud and Van Paassen 2013). Insights into contexts and power configurations are crucial, especially if one wants to avoid domination by the group who is already better positioned to assert its ideas and needs. As Barnaud and Van Paassen (2013) indicate, developing these insights takes time and renders the call for immediate cocreation of research problematic if there are not sufficient resources to address power inequalities and local dynamics. In our research program, these insights were developed over time and may have served as a starting point for multistakeholder engagements.

The structural inequalities between the various stakeholders, as well as the scale of the problems we studied, limited our abilities to explore possible solutions. We were in no position to take decisions or offer solutions that could change or shift power relations or policies, and this may have resulted in farm dwellers withdrawing from the process. It also made it difficult to develop clear directives for the workshops, as well as (realistic) outcomes and objectives. To explore the value and effects of the workshops and our research more in depth and in ways that would have any crucial outcome for farm dwellers, we would need an extension of the project far beyond the period and scope for which funding was obtained (see also Faysse 2006). In KwaZulu-Natal, the workshops contributed to generating new insights and findings to a greater extent than in the Eastern Cape because they took place during ongoing fieldwork. Some follow-up research and stakeholder engagement did take place after the research came to an end, but from different institutions and with different sources of funding, through postdoctoral fellowships and researchers pursuing careers in academia beyond the life of the NWOWOTRO program. These, over time, may help to generate further insights on the impacts of the project.

From the funder's perspective, the workshops were meant to contribute to conflict resolution based on an implicit notion of consensus being a desirable outcome. However, in our case, this perspective was problematic. Because many natural resource conflicts are about the distribution of costs and benefits, win-win solutions may not always be an option. The redistribution of costs, benefits, and risks is inherently a political issue, and addressing the needs of marginal stakeholders means that more powerful ones need to give up some of their privileges. In our case, the conflicts are related to the land question in South Africa, which is a conflict rooted in $>100$ years of systematic dispossession. The negotiated settlement and the colonial and apartheid legacies in terms of governance structures and politics are actually part of the problem (see also Voß and Bornemann 2011). In the context of game farming, land issues intersect with wildlife politics and post-apartheid land reform, as well as claims to belonging and continued violent dispossessions (Josefsson 2014, Spierenburg and Brooks 2014, Brandt 2016). In light of this situation, it was not possible to resolve cases of land-based conflicts through a limited number of multistakeholder engagements; enabling inclusion and agency for farm dwellers requires a long-term and committed process. Furthermore, game farming is not a technical or economic issue but a political issue and, therefore, requires a political solution.

In our research, participants had different assumptions about reality and their futures, although this was not always made explicit. Farm dwellers were still positioned as eternal laborers and not as potential landowners or farmers. Conservation politics in South Africa are enabled by the protection of private property, the increasing commodification of nature, and the assumption that these are suitable arrangements to enhance both ecological resilience and social transformation without one compromising the other. In light of this ideology, the (in)visibility of farm dwellers is not just a matter of their presence in multistakeholder workshops; it involves understanding and acknowledging that nature conservation, game farming, and social-ecological resilience are political issues. The underlying violent and oppressive power structures in which farm conversions take place shaped the workshops perhaps more than we were aware of at the time. This realization reinforces our conclusion that if we fail to consider power and politics explicitly as researchers, we risk neglecting important conflicts and reproducing the invisibility of marginalized stakeholders. 
Responses to this article can be read online at: http://www.ecologyandsociety.org/issues/responses. php/10265

\section{Acknowledgments:}

The findings presented here emerged from a research program entitled "Farm dwellers, the forgotten People? Consequences of conversions to private wildlife production in Kwa-Zulu Natal and Eastern Cape provinces," which was a collaborative project involving the Vrije Universiteit Amsterdam (The Netherlands), the University of the Free State (South Africa), and the University of Cape Town (South Africa). We are grateful for the funding received for this program from SANPAD (South Africa Netherlands Partnership for Alternatives in Development) and the Dutch national research foundation NWO-WOTRO, Science for Development (file number W 01.65.306.00). We thank our fellow project members Harry Wels, Shirley Brooks, Lungsile Ntsebeza, Nomalanga Mkhize, Dhoya Snijders, Tariro Kamuti, and Mnqobi Ngubane for their support in the workshops we present in this contribution. We also thank the research participants and stakeholders who participated in the workshops. We thank Sandra Evers, Heidi Dahles, Froukje Krijtenberg, Ton Salman, Anja Nygren, and participants of the workshop "Responsible professional practices for development researchers in the contemporary world," organized by the UNIPID Finnish University Partnership for International Development, University of Helsinki, 16 February 2017, as well as the editors of this special feature and the anonymous reviewers for their constructive comments on earlier drafts of this article.

\section{LITERATURE CITED}

Aliber, M., M. Baiphethi, R. de Satge, J. Denison, T. Hart, P. Jacobs, and W. van Averbeke. 2009. Strategies to support South African smallholders as a contribution to government's second economy strategy. Volume 1: situation analysis, fieldwork findings and main conclusions. Research Report 41. Institute for Poverty, Land and Agrarian Studies, University of the Western Cape, Cape Town, South Africa. [online] URL: http://hdl.handle. net/10566/391

Andrew, N., F. Brandt, M. Spierenburg, D. Snijders, and N. Mkhize. 2013. Land consolidation and the expansion of game farming in South Africa: impacts on farm dwellers' livelihoods and rights to land in the Eastern Cape. Pages 97-130 in S. J. T. M. Evers, C. Seagle, and F. Krijtenburg. Africa for sale? Positioning the State, land and society in foreign large-scale land acquisitions in Africa. Brill, Leiden, The Netherlands.

Association for Rural Advancement (AFRA). 2004. Investigation of the effects of conservation and tourism on land tenure and ownership patterns in KwaZulu-Natal. AP18. Unpublished report by McIntosh Xaba and Associates for the Association for Rural Advancement, Pietermaritzburg, South Africa.

Balvanera, P., T. M. Daw, T. A. Gardner, B. Martín-López, A. V. Norström, C. Ifejika Speranza, M. Spierenburg, E. M. Bennett, M. Farfan, M. Hamann, J. N. Kittinger, T. Luthe, M. Maass, G. D. Peterson, and G. Pérez-Verdin. 2017. Key features for more successful place-based sustainability research on social-ecological systems: a Programme on Ecosystem Change and Society (PECS) perspective. Ecology and Society 22(1):14. http://dx.doi. org/10.5751/ES-08826-220114

Barnaud, C. and A. Van Paassen. 2013. Equity, power games, and legitimacy: dilemmas of participatory natural resource management. Ecology and Society 18(2):21. http://dx.doi. org/10.5751/ES-05459-180221

Bologna, S. A. 2008. Stakeholders and stickholders: power and paradigms in a South African development context. Anthropology Southern Africa 31(3-4):123-130. https://doi.org/10.1080/233232$\underline{56.2008 .11499971}$

Bolt, M. 2017. Becoming and unbecoming farm workers in Southern Africa. Anthropology Southern Africa 40(4):241-247. http://dx.doi.org/10.1080/23323256.2017.1406313

Brandt, F. 2013. Tracking an invisible great trek: an ethnography on the re-configuration of power and belonging on trophy-hunting farms in the Karoo. Dissertation. VU University, Amsterdam, The Netherlands. [online] URL: https://research.vu.nl/ws/portalfiles/ portal/42111798

Brandt, F. 2016. Power battles on South African trophy-hunting farms: farm workers, resistance and mobility in the Karoo. Journal of Contemporary African Studies 34(1):165-181. http://dx.doi.org/ http://dx.doi.org/10.1080/02589001.2016.1200244

Brandt, F., and J. Josefsson. 2017. Sexuality and power on South African game farms; reflections on positionality and emotions in ethnographic research. Emotion, Space and Society 23:26-32. http://dx.doi.org/10.1016/j.emospa.2017.02.004

Brandt. F., and G. Mkodzongi, editors. 2018. Land reform revisited: democracy, state making and agrarian transformation in post-apartheid South Africa. Brill, Leiden, The Netherlands.

Brandt, F., and F. Ncapayi. 2016. The meaning of compliance with land and labour legislation: understanding justice through farm workers' experiences in the Eastern Cape. Anthropology Southern Africa 39(3):215-231. http://dx.doi.org/10.1080/23323256.2016.1211020

Brandt, F., and M. Spierenburg. 2014. Game fences in the Karoo: reconfiguring spatial and social relations. Journal of Contemporary African Studies 32(2):220-237. http://dx.doi. org/10.1080/02589001.2014.925300

Brodie, N. 2013. Are whites really being killed 'like flies'? Mail and Guardian 10 October 2013. [online] URL: https://mg.co.za/ article/2013-10-10-are-sa-whites-really-being-killed-like-flies

Brooks, S., and L. Kjelstrup. 2014. An anatomy of dispossession: post-apartheid land rights and farm dweller relocation in the context of a private game reserve initiative, northern KwaZuluNatal. Journal of Contemporary African Studies 32:238-257. https://doi.org/10.1080/02589001.2014.925301

Brooks, S., M. Spierenburg, L. Van Brakel, A. Kolk, and K. B. Lukhozi. 2011. Creating a commodified wilderness: tourism, private game farming, and 'third nature' landscapes in KwaZuluNatal. Tijdschrift Voor Economische en Sociale Geografie 102 (3):260-274. http://dx.doi.org/10.1111/j.1467-9663.2011.00662.x 
Connor, T. 2014. Conserved spaces, ancestral places: conservation, history and identity among farm labourers in the Sundays River Valley, South Africa. University of KwaZulu-Natal Press, Pietermaritzburg, South Africa.

Cooke, B., and U. Kothari, editors. 2001. Participation: the new tyranny? Zed Books, London, UK.

Cousins, J. A., J. P. Sadler, and J. Evans. 2008. Exploring the role of private wildlife ranching as a conservation tool in South Africa: stakeholder perspectives. Ecology and Society 13(2):43. [online] URL: http://www.ecologyandsociety.org/vol13/iss2/art43/

Cundill, G. N., C. Fabricius, and N. Marti. 2005. Foghorns to the future: using knowledge and transdisciplinarity to navigate complex systems. Ecology and Society 10(2):8. [online] URL: http://www.ecologyandsociety.org/vol10/iss2/art8/

Cundill, G. N., G. Thondhlana, L. Sisitka, S. Shackleton, and M. Blore. 2013. Land claims and the pursuit of co-management on four protected areas in South Africa. Land Use Policy 35:171-178. https://doi.org/10.1016/j.landusepol.2013.05.016

Davis, R. 2017. Analysis: the gospel according to Angus Buchan. Daily Maverick 24 April 2017. [online] URL: https://www. dailymaverick.co.za/article/2017-04-24-analysis-the-gospel-accordingto-angus-buchan/\#.WTBY1OvyjIU

Del Grande, L. 2006. The transformation of farming in South Africa and Africa: the case of farm dwellers in South Africa. Association for Rural Advancement, Pietermaritzburg, South Africa. [online] URL: https://drive.google.com/file/ d/0B2dMcP8ns05fX1FMYzlKSExlaTA/view

Deppisch, S., and S. Hasibovic. 2013. Social-ecological resilience thinking as a bridging concept in transdisciplinary research on climate-change adaptation. Natural Hazards 67(1):117-127. https://doi.org/10.1007/s11069-011-9821-9

Derkzen, P., and B. B. Bock. 2007. The construction of professional identity: symbolic power in rural partnerships in The Netherlands. Sociologia Ruralis 47(3):189-204. https://doi. org/10.1111/j.1467-9523.2007.00440.x

Devereux, S., G. Levendal, and E. Yde. 2017. "The farmer doesn't recognise who makes him rich": understanding the labour conditions of women farm workers in the Western Cape and the Northern Cape, South Africa. Oxfam, Berlin, Germany. [online] URL: https:// www.groundup.org.za/media/uploads/documents/WFP $\% 202017 \%$ 20-\%20Labour\%20Rights \%20report\%20v7\%2024-aug-2017.pdf

Dressler, W., B. Büscher, M. Schoon, D. Brockington, T. Hayes, C. A. Kull, J. McCarthy, and K. Shrestha. 2010. From hope to crisis and back again? A critical history of the global CBNRM narrative. Environmental Conservation 37(1):5-15. https://doi. org/10.1017/S0376892910000044

Du Toit, A. 1993. The micro-politics of paternalism: the discourses of management and resistance on South African fruit and wine farms. Journal of Southern African Studies 19 (2):314-336. https://doi.org/10.1080/03057079308708362

Du Toit, A. 2004. 'Social exclusion' discourse and chronic poverty: a South African case study. Development and Change 35 (5):987-1010. https://doi.org/10.1111/j.1467-7660.2004.00389.x
Du Toit, A. 2005. Forgotten by the highway: globalisation, adverse incorporation, and chronic poverty in a commercial farming district. CSSR Working Paper 101. Centre for Social Science Research, University of Cape Town, Cape Town, South Africa.

Dube, S. 2015. Muscular Christianity in contemporary South Africa: the case of the Mighty Men Conference. HTS Teologiese Studies/Theological Studies 71(3):2945. http://dx.doi.org/10.4102/ hts.v71i3.2945

East Cape Agricultural Research Project (ECARP). 2006. Advancing positive land rights and sustainable livelihoods for rural communities. Unpublished report by ECARP in co-operation with the Southern Cape Land Committee, Grahamstown, South Africa.

Edmunds, D., and E. Wollenberg. 2001. A strategic approach to multistakeholder negotiations. Development and Change 32 (2):231-253. http://dx.doi.org/10.1111/1467-7660.00204

Eriksson, A. 2017. Farm worker identities contested and reimagined: gender, race/ethnicity and nationality in the poststrike moment. Anthropology Southern Africa 40(4):248-260. http://dx.doi.org/10.1080/23323256.2017.1401484

Evans, L. K. 2010. The makings and meanings of homeland spaces: a social history of resettlement in the Ciskei, c. 1960-1976. Dissertation. University of Sheffield, Sheffield, UK.

Ewert, J., and A. Du Toit. 2005. A deepening divide in the countryside: restructuring and rural livelihoods in the South African wine industry. Journal of Southern African Studies 31 (2):315-332. [online] URL: https://www.jstor.org/stable/25064997

Fischer, J., T. A. Gardner, E. M. Bennett, P. Balvanera, R. Biggs, S. Carpenter, T. Daw, C. Folke, R. Hill, T. P. Hughes, T. Luthe, M. Maass, M. Meacham, A. V. Norström, G. Peterson, C. Queiroz, R. Seppelt, M. Spierenburg, and J. Tenhunen. 2015. Advancing sustainability through mainstreaming a socialecological systems perspective. Current Opinion in Environmental Sustainability 14:144-149. https://doi.org/10.1016/j.cosust.2015.06.002

Faysse, N. 2006. Troubles on the way: an analysis of the challenges faced by multistakeholder platforms. Natural Resources Forum 30 (3):219-229. http://dx.doi.org/10.1111/j.1477-8947.2006.00112.x

Fraser, A. 2008. White farmers' dealings with land reform in South Africa: evidence from Northern Limpopo Province. Tijdschrift Voor Economische en Sociale Geografie 99(1):24-36. http://dx.doi. org/10.1111/j.1467-9663.2008.00437.x

Hall, R. 2007. Transforming rural South Africa? Taking stock of land reform. Pages 87-106 in L. Ntsebeza and R. Hall, editors. The land question in South Africa: the challenge of transformation and redistribution. HSRC Press, Cape Town, South Africa.

Josefsson, J. 2014. Safe-guarding the colonial present: game farms on the frontier in KwaZulu-Natal's 'Battlefields Route'. Journal of Contemporary African Studies 32(2):258-274. http://dx.doi. org/10.1080/02589001.2014.925302

Kamuti, T. 2014. The fractured state in the governance of private game farming: the case of KwaZulu-Natal Province, South Africa. Journal of Contemporary African Studies 32(2):190-206. https://doi.org/10.1080/02589001.2014.936678 
Kamuti, T. 2016. Private wildlife governance in a context of radical uncertainty: dynamics of game farming policy and practice in KwaZulu-Natal, South Africa. Dissertation. University of the Free State, Bloemfontein, South Africa and VU University, Amsterdam, The Netherlands. [online] URL: http://hdl.handle. net/11660/4220

Langholz, J. A., and G. I. Kerley. 2006. Combining conservation and development on private lands: an assessment of ecotourismbased private game reserves in the Eastern Cape. Centre for African Conservation Ecology (formerly TERU) Report 56. Centre for African Conservation Ecology, Nelson Mandela University, Port Elizabeth, South Africa. [online] URL: http://ace.mandela.ac.za/ ace/media/Store/documents/Technical\%20reports/ACE-Report-56Ecotourism-based-private-game-reserves.pdf

Larson, A., and J. Ribot. 2004. Democratic decentralisation through a natural resource lens: an introduction. European Journal of Development Research 16(1):1-25.

Luck, K. 2005. Farm workers and land tenure reform: the case of game farming in Hope Fountain in the Eastern Cape. Social Dynamics 31(1):84-103. https://doi.org/10.1080/02533950508628697

Manby, B. 2002. A failure of rural protection. Transformation 49:86-104. http://dx.doi.org/10.1353/trn.2003.0004

Mauser, W., G. Klepper, M. Rice, B. S. Schmalzbauer, H. Hackmann, R. Leemans, and H. Moore. 2013. Transdisciplinary global change research: the co-creation of knowledge for sustainability. Current Opinion in Environmental Sustainability 5 (3-4):420-431. http://dx. doi.org/10.1016/j.cosust.2013.07.001

McClendon, T. V. 1995. Genders and generations apart: labor tenants, law, domestic struggle in Natal, South Africa, 1918-1944. Dissertation. Standford University, Stanford, California, USA.

McClendon, T. V. 2002. Genders and generations apart: labor tenants and customary law in segregation-era South Africa, $1920 \mathrm{~s}$ to 1940s. James Currey, Oxford, UK.

Mkhize, N. N. 2012. Private game farms and the tenure security of farm workers and dwellers in Cradock: implications for tenure reform in South Africa. Dissertation. University of Cape Town, Cape Town, South Africa. [online] URL: http://hdl.handle. net/11427/11169

Mkhize, N. 2014. Game farm conversions and the land question: unpacking present contradictions and historical continuities in farm dwellers' tenure insecurity in Cradock. Journal of Contemporary African Studies 32(2):207-219. http://dx.doi. org/10.1080/02589001.2014.925303

Nadar, S. 2009. Palatable patriarchy and violence against wo/men in South Africa - Angus Buchan's Mighty Men's Conference as a case study of masculinism. Scriptura 102:551-561. http://dx.doi. org/10.7833/102-0-614

National Agricultural Marketing Council. 2006. Report on the investigation to identify problems for sustainable growth and development in South African wildlife ranching. National Agricultural Marketing Council, Pretoria, South Africa. [online] URL: https://www.namc.co.za/wp-content/uploads/2017/09/Reporton-Wildlife-ranching.pdf
Nell, D. 2003. The development of wildlife utilisation in South Africa and Kenya, c. 1950-1990. Dissertation. Trinity College, Oxford, UK.

Ngubane, M., and S. Brooks. 2013. Land beneficiaries as game farmers: conservation, land reform and the invention of the 'community game farm' in KwaZulu-Natal. Journal of Contemporary African Studies 31(3):399-420. http://dx.doi. org/10.1080/02589001.2013.811790

Nicolson, G. 2015. Farm attacks: If only the issue were just black and white. Daily Maverick 25 August 2015. [online] URL: https:// www.dailymaverick.co.za/article/2015-08-25-farm-attacks-if-onlythe-issue-were-just-black-and-white/

Ntsebeza, L. 2013. South Africa's countryside: prospects for change from below. Pages 130-158 in F. T. Hendricks, L. Ntsebeza, and K. Helliker, editors. The promise of land: undoing a century of dispossession in South Africa. Jacana, Auckland Park, South Africa.

Parkins, J. R., and R. E. Mitchell. 2005. Public participation as public debate: a deliberative turn in natural resource management. Society and Natural Resources 18(6):529-540. http://dx.doi.org/10.1080/08941920590947977

Peires, J. B. 1981. The house of Phalo: a history of the Xhosa people in the days of their independence. University of California Press, Berkeley, California, USA.

Platzky, L., and C. Walker. 1985. The surplus people: forced removals in South Africa. Ravan, Johannesburg, South Africa.

Ramutsindela, M. 2007. Transfrontier conservation in Africa: at the confluence of capital, politics and nature. CABI, Wallingford, UK. http://dx.doi.org/10.1079/9781845932213.0000

Ramutsindela, M. 2012. Property rights, land tenure and the racial discourses. GeoJournal 77(6):753-763. http://dx.doi.org/10.1007/ s10708-010-9382-6

Scott, J. C. 1985. Weapons of the weak: everyday forms of peasant resistance. Yale University Press, New Haven, Connecticut, USA.

Snijders, D. 2014. Wildlife policy matters: inclusion and exclusion by means of organisational and discursive boundaries. Journal of Contemporary African Studies 32(2):173-189. http://dx.doi. org/10.1080/09637494.2014.937163

Snijders, D. 2015. Shifting species in South Africa: wildlife policy, rural consequences. Dissertation. VU University, Amsterdam, The Netherlands. [online] URL: https://research.vu.nl/en/ publications/shifting-species-in-south-africa-wildlife-policy-ruralconsequenc

Snowball, J., and G. Antrobus. 2008. Ecotourism and socioeconomic development: the impact of the conservation, economic and social activities of private game reserves in the Eastern Cape. Eastern Cape Private Nature Reservation Association, Grahamstown, South Africa.

Spierenburg, M., and S. Brooks. 2014. Private game farming and its social consequences in post-apartheid South Africa: contestations over wildlife, property, and agrarian futures. Journal of Contemporary African Studies 32(2):151-172. http://dx.doi. org/10.1080/09637494.2014.937164 
Spierenburg, M., H. Wels, K. van der Waal, and S. Robins. 2009. Transfrontier tourism and relations between local communities and the private sector in the Great Limpopo Transfrontier Park. Pages 167-182 in P. Hottola, editor. Tourism strategies and local responses in Southern Africa. CABI, Wallingford, UK. http://dx. doi.org/10.1079/9781845935085.0167

Stoddard, E. 2016. South Africa to limit farm sizes to speed land redistribution. Reuters 21 May 2016. [online] URL: https://www. reuters.com/article/us-safrica-landrights-reform/south-africa-tolimit-farm-sizes-to-speed-land-redistribution-idUSKCN0YCOGJ

Surplus Peoples Project (SPP). 1985. The Surplus Peoples Project research reports: Natal volume, volume 4. Surplus People Project, Cape Town, and Association for Rural Advancement, Pietermaritzburg, South Africa.

Taylor, A., P. Lindsey, and H. Davies-Mostert. 2016. An assessment of the economic, social and conservation value of the wildlife ranching industry and its potential to support the green economy in South Africa. Endangered Wildlife Trust, Johannesburg, South Africa. [online] URL: http://www. sagreenfund.org.za/wordpress/wp-content/uploads/2016/04/EWT$\underline{\text { RESEARCH-REPORT.pdf }}$

Tengö, M., R. Hill, P. Malmer, C. M., Raymond, M. Spierenburg, F. Danielsen, T. Elmqvist, and C. Folke. 2017. Weaving knowledge systems in IPBES, CBD and beyond-lessons learned for sustainability. Current Opinion in Environmental Sustainability 26-27:17-25. https://doi.org/10.1016/j.cosust.2016.12.005

Van Sittert, L. 2002. Holding the line: the rural enclosure movement in the Cape Colony, c. 1865-1910. Journal of African History 43(1):95-118. https://doi.org/10.1017/S0021853702007922

Van Sittert, L. 2005. Bringing in the wild: the commodification of wild animals in the Cape Colony/Province c. 1850-1950. Journal of African History 46(2):269-291. https://doi.org/10.1017/ $\underline{\mathrm{S} 0021853704009946}$

Van Zyl, J., J. Kirsten, and H. P. Binswanger. 1996. Agricultural land reform in South Africa: policies, markets and mechanisms. Oxford University Press, Oxford, UK.

Van Zyl, J., N. Vink, J. Kirsten, and D. Poonyth. 2001. South African agriculture in transition: the 1990s. Journal of International Development 13(6):725-739. https://doi.org/10.1002/ jid.809

Vink, N., and J. Van Rooyen. 2009. The economic performance of agriculture in South Africa since 1994: implications for food security. Development Planning Division Working Paper 17. Development Bank of Southern Africa, Halfway House, South Africa. [online] URL: https://www.dbsa.org/EN/About-Us/ Publications/Documents/DPD $\% 20$ No $17 . \% 20$ The $\% 20$ economic $\%$ 20performance $\% 20$ of $\% 20$ agriculture $\% 20 \mathrm{in} \% 20$ South $\% 20$ Africa $\% 20$ since $\% 201994-\%$ 20Implications $\% 20$ for $\% 20$ food $\% 20$ security.pdf

Voß, J.-P., and B. Bornemann. 2011. The politics of reflexive governance: challenges for designing adaptive management and transition management. Ecology and Society 16(2):9. http://dx. doi.org/10.5751/ES-04051-160209
Waldman, L. 1996. Monkey in a spiderweb: the dynamics of farmer control and paternalism. African Studies 55(1):62-86. http://dx.doi.org/10.1080/00020189608707840

Wels, H. 2015. "Animals like us": revisiting organizational ethnography and research. Journal of Organizational Ethnography 4(3):242-259. http://dx.doi.org/10.1108/JOE-12-2014-0039

Wilderman, J. 2015. From flexible work to mass uprising: the Western Cape farm workers' struggle. Working Paper 4. Society, Work and Development Institute, University of the Witwatersrand, Johannesburg, South Africa. [online] URL: http://www.global-labour-university.org/fileadmin/books/ SWOP FarmWorkers - Jesse Wilderman.pdf

Williams, G., J. Ewert, J. Hamann, and N. Vink. 1998. Liberalizing markets and reforming land in South Africa. Journal of Contemporary African Studies 16(1):65-94. https://doi. org/10.1080/02589009808729621

Yeni, S. 2018. Op-ed: 'Is government going to consult us on expropriation?' — farm dwellers. Daily Maverick 7 March 2018. [online] URL: https://www.dailymaverick.co.za/article/2018-03-07op-ed-is-government-going-to-consult-us-on-expropriation-farmdwellers/\#.WqqDYmrFLIU $\% 3$ 